
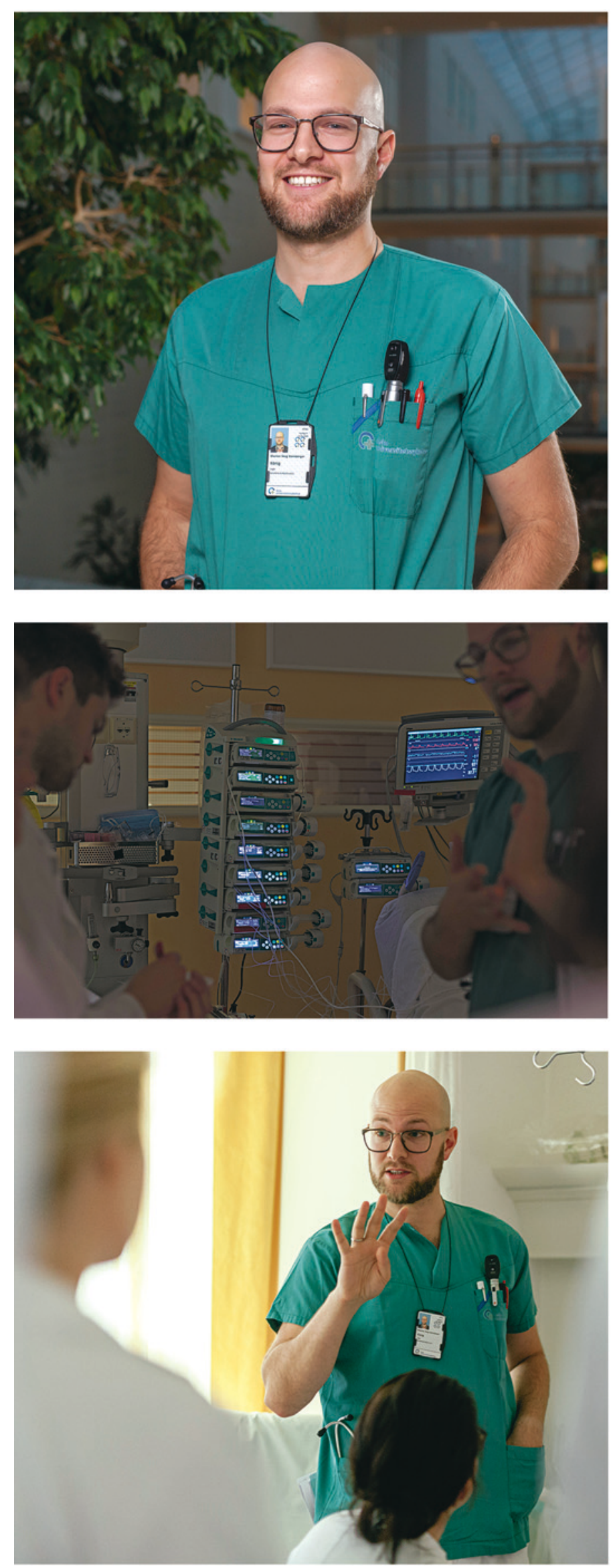

Foto: Niklas Lello

\section{Akutte nevrologer}

Marton König er lege, lektor og klinisk stipendiat ved Nevrokirurgisk avdeling, Rikshospitalet, og har tidligere jobbet som konstituert overlege i nevrologi ved Sykehuset Østfold. Han føler seg privilegert som kan drive med både nevrologi og nevrokirurgi daglig og mener disse to fagfeltene hører sammen.

\section{Skjer det noe interessant innen nevrologi for tiden?}

Ikke bare om det skjer, men hvor raskt! Nevrologi har i løpet av de siste årene utviklet seg fra å være et kronisk og ikke-invasivt fagfelt til en tidvis akutt og invasiv spesialitet. Barnevennlige arbeidsdager er blitt erstattet av belastende vakter med høyt tempo. Vi har fătt trombolytisk behandling og trombektomi ved hjerneinfarkt, levodopa og dyp hjernestimulering ved Parkinsons sykdom samt første-, andre- og nylig tredjelinjebehandling ved multippel sklerose, bare for å nevne noen eksempler. Alt dette kun i løpet av en mannsalder.

Etter mange års separasjon begynner nevrologi, nevrofysiologi, nevrokirurgi og psykiatri å finne tilbake til hverandre igjen. Tverrfaglig samarbeid med andre spesialiteter øker, og samtidig vet vi stadig mer om nervesystemet vårt, dog fortsatt ikke nok. Nevroimmunologi, nevroradiologi, nevroonkologi og nevrointervensjon er blitt født. Nevrologer landet rundt er nå ansett som en naturlig del av et akuttmottak, og andelen av pasienter innlagt som øyeblikkelig hjelp, utgjør oftest mer enn $90 \%$ av avdelingenes belegg.

Det er ikke mange år siden pasienter med hjerneinfarkt over 65 år havnet på medisinske og geriatriske avdelinger for å «avlaste» nevrologiske sengeplasser. Nå er transport med luftambulanse, slagambulanse og «rød tur» i vanlig ambulanse naturlig, forutsatt at akutt hjerneinfarkt er mistenkt. Samfunnet - og ikke minst økonomer - forstår prinsippet «time is brain» som aldri før, mens alder betyr mindre og mindre.

Faget har aldri vært så fargerikt. Sykdommene strekker seg fra kroniske degenerative - og dessverre av og til uhelbredelige - lidelser til hyperakutte tilstander, der pasienter overlever uten mén, forutsatt at riktig behandling gis i tide.

\section{Vil du anbefale en ny og spennende artikkel?}

Trombektomi, altså å fiske ut blodpropp fra et hjernekar, ble brukt verden over i økende grad siden 1999 der det var indisert, og ikke minst tilgjengelig. Nytten av denne invasive behandlingsmodaliteten var imidlertid tvetydig helt inntil nylig. Denne artikkelen symboliserer hvordan teknologisk utvikling og bevissthet om tid kan endre behandlingen og overlevelsen av en så vanlig tilstand (1). Studien måtte avbrytes på grunn av altfor stor effekt. Det skjer neppe ofte.

\section{Hva er ditt favoritthjelpemiddel på jobb?}

Utvilsomt NevroNEL (2), og den er gratis!

\section{Litteratur}

1. Saver JL, Goyal M, Bonafe A et al. Stent-retriever thrombectomy after intravenous t-PA vs. t-PA alone in stroke. N Engl J Med 2015; 372: 2285-95.

2. Norsk Elektronisk Legehåndbok. Nevrologi. http://nevro.legehandboka.no/ (12.9.2016).

Har du tips til personer vi kan intervjue? Ta kontakt med lisa.dahlbak.jacobsen@tidsskriftet.no 